\title{
Translating the Hebrew Name יהוה into the Yoruba language of Nigeria in the Yoruba Bible
}

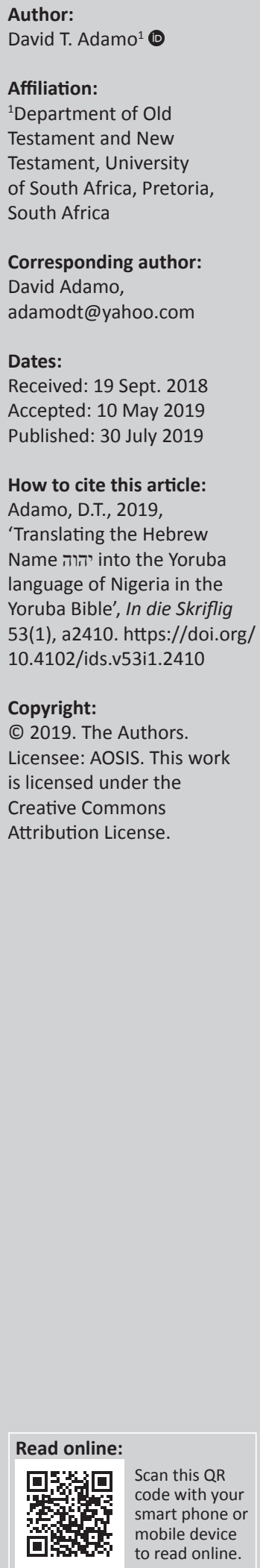

\begin{abstract}
Scholars are not unanimous about the correct pronunciation of the tetragrammaton, YHWH. The exact origin and meaning of the name have also been a subject of debate among scholars. Since translation is also interpretation, no one can give a correct translation of any word without knowing the actual meaning. While the Septuagint (LXX) translates the Hebrew word יהוה into Kurios, an English translation (New Revised Standard Version - NRSV) translates it as LORD. The translation of יהוה into the Yoruba language in the Yoruba Bible is Oluwa which I consider unacceptable. The purpose of this article is to propose the translation of the Hebrew יהוה to the most appropriate Yoruba name for the supreme God (Olodumare instead of Oluwa) which cannot be misunderstood by any Yoruba reader. ${ }^{1}$
\end{abstract}

Keywords: Old Testament; Yahweh; African traditional religion; Olodumare; Oluwa; Translation; Yoruba language.

\section{Introduction}

The name יהוה refers to the God of Israel. These four Hebrew letters are referred to as tetragram or tetragrammaton by scholars (Hamilton 2011:64; Shaw 2016:759-762). Tetragrammaton comes from a Greek word $\tau \varepsilon \tau \rho \alpha \gamma \rho \alpha ́ \mu \mu \alpha \tau o v$ and a Latin script YHWH which literally means four letters and יהוה in Hebrew. The name appears more than 6823 times in the Old Testament (Renn 2005:339-440). The fact that the vowel signs in the tetragrammaton were not represented in the writing system, originally led to the question of what vowels should apply to it or how to pronounce it (Ortiepp 2011:12).

Most of the earlier translators of the Yoruba Bible may not have understood the original languages directly (Komolafe 2012). What appears to compound the situation is that the European supervisors of the Yoruba Bible translators were not native speakers of the Yoruba language (BibeliMimo 1900).

Given that the word יהוה is translated to 'LORD' in the English versions of the Bible (e.g. King James Version [KJV] and Revised Standard Version [RSV]), it is assumed that it means Oluwa in the Yoruba Bible. Because of this, the translators of the Yoruba Bible (BibeliMimo and Bibeli Yoruba Atoka) translated Yahweh to Oluwa and Jehofa. I believe such translations are inappropriate. I propose that a better translation is Olodumare. What appears to be a more serious problem is the fact that, to my knowledge, there have been no attempts to correct these inappropriate Yoruba translations.

The purpose of this article is to express the problems with the present translation of the Bible into the Yoruba language and to suggest a more appropriate translation of the name Yahweh in the Yoruba Bible. This article also emphasises the urgent need for a retranslation of the Yoruba Bible by competent native scholars who are experts in Hebrew, Greek and the Yoruba languages. ${ }^{2}$

To achieve the above objectives, this article discusses the origin and meaning of the name as well as the translation of it into the Greek, English and Yoruba versions of the Bible. Various translation theories, attempted for a credible translation, will be briefly surveyed. As there has

1.There are many other words in the Old Testament that have been mistranslated into the Yoruba language. These include the Old Testament book titles such as Genesis to Genesisi, Exodus to Exodu, Numbers to Numeri, Leviticus to Lefitiku, Deuteronomy to Deuteronomi and Psalms to Orin Dafidi (Adamo 1984:454-482). Thus, there is an urgent need to retranslate the entire Yoruba Bible into the Yoruba language from Hebrew and Greek.

2.The Yoruba people, often considered to be one of the largest ethnic groups in Africa south of the Sahara, are primarily located in Southwestern Nigeria. There are also a few Yoruba people in Benin and Togo.

Note: This article was originally presented as a paper at the SASNES/OTSSA conferences at the North-West University, Potchefstroom, South Africa on 14-16 August 2018. This article does not represent a lack of appreciation for the contribution of missionaries. God has used whatever mistakes they made to bless us in Africa. I am a product of those blessings. 
been no single perfect translation theory from the numerous suggestions, an attempt will be made to use a combination of theories that may apply to this article. Among the principles which may be used to achieve this, is a combination of dynamic equivalence, linguistic, cultural and postcolonial translation theories.

\section{Origin and meaning of the name יהוה Origin}

Exodus 3:13-15 has been a subject of debate among scholars. ${ }^{3}$ The number of interpretations of the meaning and functions of the divine name in the text of Exodus 3:14, which have been proposed over many centuries, seems endless. One can only mention a few of them.

In Exodus 3:14, Moses asks God how he should answer his people when they ask for his name. God gave him three answers in verses 14 and 15 (Phillips 1998:81-84):

1. 'I am who I am' (3:14a - NRSV).

2. 'I am has sent me to you' (3:14b - NRSV).

3. 'Tell the Israelites, God of Abraham, Isaac and Jacob, has sent me to you' (3:15- NRSV).

What appears to be the author's concern in Exodus is the identification of the God of the forefathers and the God who appears to Moses in the burning bush (Phillips 1998:81-84).

There have been debates regarding the origin of the word יהוה, and whether it was newly created by Moses or premosaic. While some scholars believe that the name existed before Moses and that Moses took it from an earlier tradition, others believe that Moses invented it (Foerster 1965:1065-1066; Mowinckel 1961:21-23). Many reasons for this view are cited. Firstly, such a name was found in Akkadian proper names and in Ras Shamra texts which dated as far back as the 15th to 13th centuries BCE (Foerster 1965:1065-1066); secondly, in Egyptian or African religions, especially Amon Re, referrence to the 'King of the gods', is also cited as the possible origin of the Yahweh religion that has contributed to Yahweh theological tradition (Foerster 1965:1065-1066); thirdly, also the Kennite hypothesis is cited as a reason, because Moses became the son-in-law of Jethro, the priest of Midian, who worshipped Yahweh before Moses. It was therefore suggested that Moses was bound by oath to his father-in-law and that is why he later adopted the name יהוה (Jdg 1:16; Foerster 1965:1066); and fourthly, the primitive abbreviation Yah that is related to the moon cult Ya-huwa, which means 'oh he', could also be a reason (Mowinckel 1961:21-23).

3.According to Phillips (1998:81-84), the first person singular of the verb to be, I am in Exodus $3: 14$, is a later interpolation and attempt to explain the meaning of the divine name Yahweh. Exodus 3:14b is a redactional transition to verse 15, probably inserted by the Proto-Deuteronomists and that, in their revision of the Sina narrative, they introduced verse 14 (Phillips 1998:81-84). Exodus $3: 14$ a is also narrative, they introduced verse 14 (Phillips 1998:81-84). Exodus 3:14a is also regarded as an interpolation derived from Hosea 1:9 (Phillips 1998:81-84). The answer to Moses' question is, in the first place Yahweh; and secondly, who the God of the fathers is. There is only one place where the word היהא was used in the Old Testament, viz. in Hosea, which many scholars believe that it has a reference to Exodus 3:14. It means that the covenant relationship established with Israel in Sina has been terminated. However, Phillips (1998:81-84) thinks that Hosea should be interpreted independently of Exodus 3:14.
Several scholars have rejected the above theories (Beitzel 1980:5-20; Foerster 1965:1066; Hamilton 2011:64; Jacob 1964:48; Kearney 2002:75-85). It is suggested that it originated from the verbal root היה or. Beitzel 1980:5-20) believes that the relationship between the verb הוה and the divine name Yahweh is that of etymology. It means that the origin of the יהוה is from God's lips itself, according to the Exodus 3 tradition (Foerster 1965:1066).

\section{Meaning}

Different commentators interpret the words אהיה אשר אהיה differently. Some believe the words are an ambiguous and contradictory answer to Moses' question when he asked God for his name in Exodus 3:14 (Sachs 2010:244-246). According to Sachs (2010:244-246), אהיה means 'I am', or 'I shall be', because it signifies an action that is not yet concluded and therefore אהיה אשר אהיה can mean different ways of 'self-definition'. Firstly, 'I am who I am', which refers to 'an eternally unchanging Being'; secondly, 'I am who I shall be', which stands for 'a fundamental constancy regardless of variations'; thirdly, 'I shall be who I am', which is 'the evolution that is inherent in the essence of God'; and fourthly, 'I shall be who I shall be', which can also have two meanings: 'To everyone I am something else', or 'each person has a different idea of me'.

According to Schild (1954:296), 'I am who I am' is regarded as the explanation of the meaning of the divine name which connects with the root of the verb 'to be' (היה). This verb 'to be' has two connotations: expression of 'identity' or 'existence'. This verse is meant to express the mystery of God and how impossible it is to define his name (Schild 1954:296-302). According to Schild (1954:296-302), 'I am' means therefore 'I am not telling you who and what I am', or 'I am I'. In other words, God cannot be defined. He is his own definition.

No doubt the Hebrew Bible calls God different names ranging from generic to the proper. Examples of the generic names is El or Elohim, Adonai and others. Adonai, which is used very frequently, is the traditional and pious reading replacement of the proper name of God, namely יהוה (Sonek 2009:174-183). Barton (1998:1-6) has rightly said, 'in every age, interpreters ask different questions, and so different aspects of the text's meaning emerge'. Thus, a new meaning of the text also emerged in the interpretative process according to the readers' presupposition and interest. There is therefore the need for constant reinterpretation (Sonek 2009:174-183).

According to Sonek (2009:174-184), there are two major ways of interpreting Exodus 3:14: positive and negative. The positive way is to interpret the tetragrammaton as a disclosure of the nature of God; and the negative way of interpreting the text of Exodus 3:14 is that both the names and its literary context conceal the nature of God.

A closer examination of Exodus 3:13-15 shows that it contains parallel phrases and two divine names of God, namely Yahweh and Elohim. Some people see these two 
names as an indicator of the passage coming from two different sources. Yahweh is a personal name, while Elohim is a generic name (Hertog 2002:213-228).

In Exodus 3:13, the generic name of God is used. Moses asked God, 'If I say to the Israelites', 'God [Elohim] of your ancestors has sent me to you', and they ask me, 'What is his name?', what shall I say to them?' (NRSV). Here, Exodus 3:14 is supposed to be the explanation of the Name of God (עֶשר אהיהאהיה [I am who I am], v. 14; [I am has sent me to you], v. $14-\mathrm{NRSV})$.

Exodus 3:15 uses the name of God in its proper form, namely יהוה. God told Moses, 'The Lord (יהוה), the God of your ancestors, the God of Abraham, Isaac and Jacob, has sent me to you' (Ex 3:15). 'This is my name forever, and this is my title for all generations' (Ex 3:15 - NRSV; Sonek 2009:174-184). Thus, the tetragrammaton was to supplement the name Elohim (Kearney 2002:75-85). Yahweh is more of a name of invocation that makes God more personal and eschatological. In other words, God ceases to be the 'unnameable, the inaccessible, ... and impassable' (Kearney 2002:75-85). The name revealed to Moses, is not some kind of secret name or essence, but as God who is the coming God who may be (Kearney 2002:75-85). The name יהוה can be understood to be qal imperfect third person singular form of the verb to be היה. If it is a qal imperfect singular third person, it should mean 'he is', 'he will be', or 'he who exists' (Sonek 2009:174-184). However, if the name is taken as the hiphil form of היה, the meaning will be 'he who causes things to exist', or 'he who causes events to happen' (Brownlee 1977:39-46; Sonek 2009:174-184).

The revelation of the name of God in Exodus 3:13-15 serves two purposes. Firstly, it confirms that the same God who speaks to Moses is the same One who spoke to Abraham, Isaac and Jacob (v. 15); and secondly, Exodus' name reassures Moses and the Israelites that God will also be with them at all times (Sonek 2009:174-184).

Apart from Exodus 3:14, no other passage in the Old Testament tries to explain the actual meaning of the word יהוה. Scholars have not been able to reach a unanimous agreement concerning the linguistic meaning of the tetragrammaton. One scholar (Beitzel 1980:5-20) proposes that it is fruitless to try to know the meaning of the tetragrammaton, because the original form Yah, Yahuor Yo was just an 'emotional ejaculation' or 'solemn cultic cry'.

According to Hamilton (2011:64), the term אהיה is the first person imperfect of the verb היה which means 'I was', 'I am', and 'I will be', and may also mean 'that', 'what' and 'who'. Hamilton (2011:64) believes that אהיה אשר אהיה. could be translated in the following ways:

1. 'I who I am';

2. 'I am who I was';

3. 'I am who I shall be';

4. 'I was who I am';
5. 'I who I was';

6. 'I was who I shall be';

7. 'I shall be who I am';

8. 'I shall be who I was';

9. 'I shall be who I shall be'.

The nine suggested meanings above suggest the same meaning stated in different ways and in different tenses.

\section{Translation of יהוה into English versions}

The LXX translated the Hebrew word יהוה to Kurios. It appears 9000 times in the LXX (Bintenhard 1976:511). ${ }^{4}$ In this case, the LXX seems to strengthen the Jewish tendency of avoiding the utterance of the name יהוה (Mundhenk 2010:58-63; Oseka 2016:13-44). When the KJV was translated, the word Yahweh was translated as LORD; thus following the later translation of the LXX to Kurios. In 1901, the revision done by the 'American divines', The American Standard Version (ASV), retained the term LORD. The same term is used in the RSV of 1952 which sets out to make the Bible clearer to the public by changing some of the archaic words. The New American Standard Version (NASV) of 1960 used this same term in some of its passages. The Jerusalem Bible (TJB) and the New International Version (NIV) used the same word, viz. LORD.

\section{Translating the name יהוה into the Yoruba language in the Yoruba Bible}

The first translation of the Yoruba Bible, BibeliMimo, was printed in 1884 and reprinted in 1900. Bishop Ajayi Crowther played a significant role in the translation. He was supervised by British missionaries (BibeliMimo 900). There is also a 1959 edition in which some of the misprinting and other incorrect words were replaced by the United Bible Society. Some of the words that were revised are:

- okorin becomes okunrin - wrong spelling of a male is corrected;

- obirin becomes obinrin - wrong spelling of a female is corrected;

- Ndao becomes Rara o (Lk 22:35) - a word (no), which is not even a Yoruba word, is corrected;

- daiyafo becomes daiyaja (Dt 1:28) - the correct spelling of the phrase 'to fear', is corrected;

- Gabasi becomes Ila orun (Nm 2:3) - the wrong word, which is not even a Yoruba word, is corrected to 'rising sun';

- yama becomes orun (Ez 41:12) - the wrong word, which is not even a Yoruba word, is corrected to 'sun';

- Nos becomes Mose (Ex 18:12) - the name of Moses is corrected;

- ogboni becomes okunrin (Ez 23:23) - the wrong word, which means a male, is corrected;

- Olodo becomes Olododo (1 Cor 1.9) - the wrong word (zero) is corrected to righteousness.

4.The word in the LXX, refers to men about 190 times and 15 times to ba'al. The word can also refer to a commander, ruler or lord. 
In 1980, another version of the Yoruba Bible (Bibeli Yoruba Atoka) was translated into modern Yoruba language with references or concordance. It translated יהוה to Jehofa.

\section{Translation principles}

Although the purpose of this article is not the discussion of translation theories, I believe that it is important to mention various major translation theories before arriving at the suggested translation of the Hebrew name יהוה into the Yoruba language in the Yoruba Bible. I will begin with E.A. Nida (1914-2011), who is regarded as the most distinguished and influential theorist of Bible translation of the 20th century. He is best known for the concept of dynamic equivalence - later renamed as 'functional equivalence' (Cheung 2011:51). Nida's work came into prominence in the 1960s after publishing his books, Toward a science of translating (1964) and The theory and practice of translation (1969). The 1960s has been described as 'The age of equivalence' (Malmkjær 2005:5; Pym 2004:44). Four of Nida's translation principles are still notably crucial to this work. Firstly, a translator must reproduce the meaning of the passage as understood by the writer (Nida \& Taber 1982:8); secondly, the translator must choose the closest or most natural equivalent meaning (Nida \& Taber 1982:8); thirdly, meaningless words or vocabularies must be avoided in the text (Nida \& Taber 1982:30); and fourthly, priority must be given to the need of the audience or readers about the forms of the written language (Nida \& Taber 1982:31). According to Robert Bratcher (1999:588), a translator has three tasks: firstly, to determine the form of the original text; secondly, to ascertain the meaning of the original text; and thirdly, to transfer the meaning to the target language in such a way that the readers of the translation understand it as did the readers of the original. Other scholars were concerned about the dynamic equivalence and that translators should find the dynamic equivalence of the original language (Kiboko 2017:32-36; Thomas 1990:161).

Since Nida's translations, some changes have taken place in the form of improvement in translation theory. A shift from source-text to target-text oriented theories and a shift, which includes cultural and linguistic factors in translation theory, took place (Gentzler 2001:70). By 1965, J.C. Catford went further than Nida by borrowing the ideas and terminologies from linguistics, because he (Catford 1965:19) believed that 'the theory of translation is essentially a theory of applied linguistics'. According to Catford (1965:1), the definition of translation is 'a process of substituting a text in one language for a text in another'. He introduced two major categories to translation, namely 'rank-bound' and 'unbounded' translations (Cheung 2011:56). Catford (1965:27) also introduced a distinction between formal correspondence and textual equivalence.

By 1970, translation theorists started moving away from linguistic approaches to a wider view of translation of social and political perspectives. This development came at a time of 5.It was mentioned above that such translation is inappropriate. 'cultural turn' with the rise of 'interdisciplinary development in the humanities and social sciences' (Cheung 2011:57).

George Steiner (1975:378), who championed the development of functionalist approaches, was best known for his 'Hermeneutic Motion'. He thought that translation ranged widely across philosophy, literature and hermeneutics. His (Steiner 1975:312) key contribution to translation theory is his form of four-step hermeneutic motion called 'The act of elicitation and appropriative transfer of meaning'. The four motions by which he set forth his description, are trust, aggression, incorporation and restitution (Steiner 1975:296-303).

The year 1980 was the period of change from a formalist and linguistic approach to the emphasis on extra-textual factors and cross-cultural interaction (Cheung 2011:60). 'Cultural turn' has to do with a 'movement across the social science to incorporate matters of socio-cultural convention, history and context' (Cheung 2011:60; Snell-Hornby 2006:47). Gentzler (2001:70) advocated for 'target-text oriented theories' by which he meant functionalist approaches such as the skopos theory.

The best known functionalist approach is the skopos theory developed by Hans Vermeer. According to Reiss and Vermeer (1984:119), the overriding rule for skopos is that the target text should be determined by its function, and what is most important is whether it is fit for the purpose or not. According to this theory, ' $[t]$ he primary aim of the translator is to fashion a target text that is functional in the target audience community' (Cheung 2011:60). As far as functional approaches are concerned, what makes a translated text good is whether it is fit for a purpose or not, and in the words of Christiane Nord (1997:29), 'the ends justify the means'.

In 1991, Ernst-August Gutt developed a translation and relevance theory with a cognitive approach to translation. According to Gutt, communication is dependent on inferential processes (Cheung 2011:64). The central claim of the relevance theory is that human communication creates an expectation of optimal relevance that there are 'direct' and 'indirect' translations. While the 'direct' translation 'purports to interpretively resemble the original completely' (Gutt 1991:163), the 'indirect translation yields the intended interpretation without causing the audience unnecessary processing effort' (Cheung 2011:67; Gutt 1991:42).

Foreign translation was advocated by Lawrence Venuti. Observing that literary works were almost universally domesticated, Venuti (1998:12) argued that target cultures would be better served with foreign translations.

Rasiah Sugirtharajah (2002:135-148) is one of the specialists in postcolonial translation theory. Postcolonial translation theory deals with the examination of how the translation was practiced in the former colonial cultures; how the works of the writers from former colonies were translated into other languages; and the actual historical role played by translation 
in the process of colonisation. In a way, postcolonial translation overlaps with the foreign theory in the area of resistance and power balancing (Cheung 2011:73-74).

It is impossible to survey all the various translation theories in this article. However, it is important to mention that none of the above theories is perfect and the use of a combination of some of them can be important and helpful. In this case, both the equivalence, skopos and postcolonial theories, which overlap with African biblical hermeneutics and not only takes the language of the people very seriously, but also their culture and religion, are useful for this article.

\section{The translation of Yahweh to Oluwa in the Yoruba Bible}

In most current editions of the Yoruba Bible, the name יהוה is translated to Oluwa with the exception of Bibeli Yoruba Atoka (1980) which transliterates the name to Jehofa. It is not acceptable, because it is meaningless to Yoruba Christians. When we consider the meaning of Oluwa in Yoruba, it is equally not acceptable even though it was translated as such and are in use in almost all the Yoruba Bibles. There are some reasons why I object to the translation of Yahweh to Oluwa. Despite the universal acceptance of Oluwa by the Yoruba people, as translated in the Yoruba Bible, I strongly believe that such word cannot be appropriate for Yahweh according to the meaning in the Hebrew language. As discussed above, the name יהוה means a unique and incomparable God, whereas Oluwa is not a name, but a title. This title literally means 'master'. The title Oluwa, as the word 'Lord', can be given to any person in a higher position such as a military officer, teacher or any helper, mother or father. It can be used as a description of any god. In other words, the divine element is absent from the title Oluwa.

Despite the disagreement among scholars concerning the meaning and origin of the name Yahweh, there is some universal agreement among scholars that it originated from the revelation in Exodus 3 and that the root of the Hebrew word הוה is היה or As discussed above, there seems to be a general agreement among scholars that היה is the first person imperfect of the verb which means 'I was','I am' and 'I will be', and may also mean 'that','what' and 'who' (Hamilton 2011:64). From the above meanings, Oluwa is not appropriate for Yahweh in the Yoruba Bible.

According to the Yoruba creation myths, there were four primordial beings or divinities who originally contended for superiority with the supreme Being, Olodumare. Olodumare, however, eventually demonstrated his superiority to the divinities (Oduyoye 2008:17-20). The result is that the Yoruba people, especially Christians, see Olodumare alone as the supreme Being and all other beings or gods are nonexisting. Olodumare is unique. Because of the supremacy and the uniqueness of Olodumare, the name 'Olodumare' is never applied to any human being or to any other god. No Orisa or divinity is called Olodumare. Whereas the divine element is absent in the title 'Oluwa', it is part and parcel of Olodumare, who is unique. From the above principles of translation, I believe that the most appropriate translation of יהוה is Olodumare which is a name, instead of Oluwa, which is a title.

There are many Yoruba names that can be used for the supreme Being, but two of them are more prominent: Olorun and Olodumare (Yahweh Elohim). ${ }^{6}$ The translators of the Yoruba Bible and Yoruba Christians accepted the above translation to Oluwa instead of Olodumare as the equivalent of Yahweh. Considering the above, it is difficult to understand why the translators of the Yoruba Bible prefer Oluwa to Olodumare as the correct translation of יהוה. Perhaps one of the reasons is, that the Europeans who were the supervisors of the Yoruba translators were not native speakers of Yoruba and so did not understand the Yoruba language as thoroughly as they claimed to. It is also possible that the translators followed the idea of latter Judaism of not pronouncing the holy name of יהוה in order not to profane his holy name. Another possible reason is the practice of copying the English version of the Bible verbatim which copied the Greek (LXX) translation verbatim in translating YHWH to 'Lord', which means Oluwa in the Yoruba language.

I prefer the translation of יהוה to Olodumare instead of Oluwa in the Yoruba Bible because of the meaning and the attributes of Olodumare. While Oluwa simply and literally means 'master' or 'Lord', Olodumare has a deeper meaning, similar to Yahweh in his attributes and nature, יהוה. The word Olodumare has three words joined together, Ol-Odumare. While the $\mathrm{Ol}$ is a prefix, which means 'owner of' or 'lord of', Odu literally means 'very large','very extensive', 'very full', 'of superlative quality and worth,' or 'superlative in greatness, size, quality and worth' (Adamo 2017:13-16; Idowu 1960:34). The two together, 'Olodu' means someone who is a supreme head, one who possesses the sceptre of authority, or one who 'contains' the fullness of excellent attributes, or one who is superlative and perfect in greatness, size, quality and worth (Idowu 1960:34). Mare is a descriptive adjective meaning 'that does not go', 'that does not move or wander', 'that remains', and it has the implication of the fact that Olodumare, the supreme Deity who possesses superlative qualities, also has the 'attribute of remaining stable, far unchanging, constant, permanent and reliable' (Adamo 2017:15-16; Idowu 1960:34). According to Idowu, Olodumare means 'splendour, majesty-light and glory which God wears as king' (1960:36). Thus, the meaning of Olodumare is 'one who is supreme, superlatively great, incomparable and unsurpassable in majesty, excellent in attributes, stable, unchanging constant, reliable' (Adamo 2017:15-16; Gbadegesin 2018:45). ${ }^{7}$ Olodumare, the Yoruba name for God (YHWH) is considered the hidden and yet relevant God (Gbadegesin 2018:44).

6.As far as I am concerned, the translation of the name of God, El, Elohim to Olorun has no contention.

7.Olorun is another name for Olodumare and is self-explanatory. It has $\mathrm{Ol}$, which is the .Olorun is another name for Olodumare and is self-explanatory. It has Ol, which is the
prefix that means 'owner of' or 'lord of', as said above. The other part is Orun which prefix that means 'owner of' or 'lord of', as said above. The other part is Orun which
literally means 'heaven'. Olorun therefore, means the owner or Lord of heaven (Idowu 1960:38-47). 
Lucas (1948) also defines the word Olodumare as:

... Olodu is its intensive form, indicating completeness (e.g. biro 'woman'; lobar 'a woman in the full bloom of womanhood'). Mare means 'I shall go or I must go'. The meaning of Olodumare then is 'the Chief or the Exalted One to whom I must go or return'. (p. 40; Adamo 2017:16)

Modupe Oduyoye (2008:31) sees the variant of this same name as Edumore which he describes as 'the splendid, the glorious, full and whole'. Olodumare is 'the one who has wholeness of splendour - the Lord clothed in glorious light'. He (Oduyoye 2008:32) goes further to say that Olodumare is not a name: it is shown by the $\mathrm{Ol}$ - prefix to be a title ('owner of ...'), just as Ol-prefix in Olorun shows it to be a title ('the owner of heaven'). Olodumare is a name and not a title in theYoruba language.

However, Ayo Bamigbose dismissed Idowu's and Oduyoye's definition and explains the meaning of Olodumare as odu. Part of the word Olodumare means 'bigness, vastness' (cited by Oduyoye 2008:34). Bamigbose continues to declare that the first part of $\mathrm{Ol}$ - (oni) should not be interpreted as a prefix of ownership: 'Olodumare is merely an intensive variant of Edumare or Odumare just as onimale is not the owner of imole' (cited by Oduyoye 2008:34). According to Bamigbose, Olodumare means 'The immensity of heaven' and not the 'Lord or owner of the immensity of heaven' (cited by Oduyoye 2008:34). The name that 'stands above every other name, that is, Olodumare, is the owner of the Deity' (Idowu 1960:32).

Some Western biblical scholars who may not be very familiar with Yoruba religion and tradition may have problems accepting the fact that Olodumare refers to Yahweh, the God of Israel just as one Western scholar and anthropologist, Emil Ludwig, was so perplexed and puzzled when he was told that missionaries were teaching Africans about God. Ludwig asked, 'How can the untutored African conceive God? ... How can this be? Deity is a philosophical concept which savages are incapable of framing' (quoted by Adamo 2017:15-17; Idowu 1960:30). The names and attributes of Olodumare may further convince some Western scholars that the translation of יהוה to Olodumare in the Yoruba Bible is more appropriate than Oluwa.

According to the Yoruba religion and tradition, the following are the names of Olodumare, the supreme Being (Adamo 2017:15-16; Awolalu 1979:vii, 10-12):

1. Olorun which literally means the owner of heaven;

2. Eleda which means the Creator;

3. Alaaye which means the owner of the earth;

4. Elemi which means the owner of Life;

5. Olojooni which means the owner of the day;

6. OgaOgo which means Lord of glory;

7. Atererekariaiye which means the one who spreads across the entire universe.

Of all these names, Olodumare is the most appropriate translation of יהוה.
The attributes of Olodumare are the following (Awolalu 1979:vii, 12-18; Gehman 1989:189-194; Idowu 1960:38-47; Mbiti 1970:31-41): ${ }^{8}$

1. omnipotent;

2. omniscient;

3. transcendence;

4. king and judge;

5. uniqueness;

6. immortality;

7. holiness;

8. mercy;

9. goodness;

10. faithfulness.

It is important to note that the majority of scholars of African religion and the majority of African Christians have no doubt that Olodumare is the supreme Being and the same as the God of Israel who has not left himself without a witness all over the world (Gehman 1989; Idowu 1960; Mbiti 1970; Oduyoye 2008:17-20; Parrinder 1962; 1961).

\section{Conclusion}

I have discussed the various scholarly opinions about the origin and meaning of $\mathrm{YHWH}$ and have accepted the majority opinion that the word $\mathrm{YHWH}$ originated from the verb to be, in Exodus 3:13-15. It means the ever-active God who was, who is and who will be. From my analysis of the translation of the Hebrew Bible to Greek, English and the Yoruba language of Nigeria, I believe that the translation to Kurios by the LXX and to LORD by the English version is not the best in light of the meaning of LORD in the Yoruba language. Unfortunately, the translators of the Yoruba Bible followed the LXX and English translation verbatim and translated the word $\mathrm{YHWH}$ to Oluwa which I consider to be inappropriate.

On this basis, and in regard of the great similarity of meaning and attributes of יהוה and Olodumare in the Yoruba religion and tradition, Yahweh should be translated to Olodumare in the Yoruba Bible instead of Oluwa. Even though some human names can be insulting, no name of God in the Bible and Yoruba culture represents an insult. Therefore, no name of God in the Yoruba Bible should be transliterated. There is no name of God in the Bible and African culture that cannot be captured in the Yoruba language when translated, as these names have meanings in both the Hebrew and Yoruba traditions. Translation of God's name into the Yoruba language has several advantages. Firstly, the indigenous people will be more familiar with the Bible; secondly, the indigenous society understands the Bible better; thirdly, while names of God in the Bible and in the Yoruba language have meanings and most of the time represent the nature of God, the translation of God's name into the Yoruba language will help Yoruba readers to understand the nature of God; and fourthly, consequently Christianity will be more indigenised in Africa. It will reduce the anti-colonial opinion that the Bible is a foreign book and Christianity a foreign religion.

8.For further names and attributes of Olodumare, see Samuel Osunbuyide (2014:37, 40) in Orikinile Yoruba. 
Finally, having briefly discussed the history of translation from Hebrew to Greek and to English and Yoruba, I suggest that the Old Testament in the Yoruba Bible should be retranslated from the original languages by scholars who understand not only the original languages, but also the Yoruba language. It is my hope that such a retranslation of the Bible into the Yoruba language will be a continual process and that such translations will not only increase the understanding of the Scriptures, but also contribute to the health and growth of the churches and communities who read or engage in the worship life of the church.

\section{Acknowledgement Competing interest}

The author declares that no competing interest exists.

\section{Author contributions}

I declare that I am the sole author of this research article.

\section{Funding}

This research received no specific grant from any funding agency in the public, commercial, or not-for-profit sectors.

\section{Data availability statement}

Data sharing is not applicable to this article as no new data were created or analysed in this study.

\section{Disclaimer}

The views and opinions expressed in this article are those of the author and do not necessarily reflect the official policy or position of any affiliated agency of the authors.

\section{Ethical consideration}

This article followed all ethical standards for carrying out research without direct contact with human or animal subjects.

\section{References}

Adamo, D.T., 1984, 'The problem of translating the Hebrew Old Testament book titles into Yoruba language of Nigeria', The Bible Translator 35(4), 418-424. https://doi. org/10.1177/026009438403500404

Adamo, D.T., 2017, 'Psalm 100 in African context', Journal of Semitics 27(2), 1-23. https://doi.org/10.25159/1013-8471/4186

Awolalu, J.O., 1979, Yoruba beliefs and sacrificial rites, Longman, London.

Barton, J., 1998, 'Introduction', in J. Barton (ed.), Cambridge companion to biblical interpretation, pp. 1-6, Cambridge University Press, Cambridge.

Beitzel, B., 1980, 'Exodus 3:4 and the divine name: A case of biblical paronomais', Trinity Journal 1(1), 5-20.

BibeliMimo Atoka, 1980, Kaybal Foundation Limited, Ibadan.

BibeliMimo in Yoruba, 2006, The Bible Society of Nigeria, 1900 edition reprinted in Brazil.

Bietenhard, H., 1976, 'Lord, Master', in C. Brown (ed.), The new international dictionary of New Testament theology, pp. 511-512, Zondervan, Grand Rapids, MI.

Bratcher, R.B., 1999, 'Translation', in J. Hayes (ed.), Dictionary of biblical interpretation, pp. 588-591, Abingdon, Nashville, TN.

Brownlee, W.H., 1977, 'The ineffable Name of God', BASOR 226, 39-46. https://doi. org/10.2307/1356574
Catford, J.C., 1965, A linguistic theory of translation, Oxford University Press, Oxford.

Cheung, A., 2011, 'Functionalism and foreignisation: Applying skopos theory of Bible translation', Ph D Thesis, University of Birmingham, UK.

Crowther, A.S., 2019, 1st Bible translated in Yoruba, Inside 1st Storey, viewed 10 January 2019, from https://www.nairaland.com/2545954/1st-bible-translatedyoruba-ajayi.

Foerster, K., 1965, 'Kurios,' in G. Kittel (ed.), (Kurios) theological dictionary of the New Testament, vol. 3, pp. 1065-1066, Eerdmans, Grand Rapids, MI.

Gbadegesin, E.O., 2018, 'Olodumare: The hidden but relevant God in the Yoruba religious imagination', in E.K. Bongmba (ed.), Religion and social reconstruction in Africa, pp. 44-55, Routledge, London.

Gehman, R., 1989, African traditional religion in biblical perspective, Kesho Publications, Kijabe.

Gentzler, E., 2001, Contemporary translation theories, 2nd edn., Multilingual Matters, Clevedon.

Gutt, E.-A., 1991, Translation and relevance: Cognition and context, Blackwell, Oxford. Hamilton, V., 2011, Exodus, Baker Academic, Grand Rapids, MI.

Hertog, C.D., 2002, 'The prophetic dimension of the divine Name: On Exodus 3:14a and its context,' Catholic Biblical Quarterly 64(2), 213-228.

Idowu, B., 1960, Olodumare: God in Yoruba belief, SPCK, Ibadan.

Jacob, E., 1964, Theology of the Old Testament, Westminster, Philadelphia, PA.

Kearney, R., 2002, 'God who may be: A phenomenological study', Modern Theology 18(1), 75-85. https://doi.org/10.1111/1468-0025.181177

Kiboko, J.K., 2017, Divining the woman of Endor, African cultural, post-colonia hermeneutics, and the politics of biblical translation, Bloomsbury, New York.

Komolafe, J., 2012, Of translation, vernacularization, and appropriation: Reevaluating Bishop Ajayi Crowther in Yoruba spirituality, viewed 19 February 2019, from $\mathrm{http}: / /$ saharareporters.com/article/esu-revenge-bishop-ajayi-crowther.

Lucas, O., 1948, The religion of the Yorubas, C.M.S. Bookshops, Lagos.

Malmkjær, K., 2005, Linguistics and the language of translation, Edinburgh University Press, Edinburgh.

Mbiti, J.S., 1970, Concepts of God in Africa, SPCK, London/

Mowinckel, S., 1961, 'The Name of God of Moses', Hebrew Union College Annual 32, 21-33.

Mundhenk, N., 2010, 'Jesus is Lord: The tetragrammaton in Bible translation', The Bible Translator 61(2), 55-63. https://doi.org/10.1177/026009351006100201

Nida, E.A. \& Taber, R., 1982, The theory and practice of translation, United Bible Societies, Leiden.

Nord, C., 1997, Translating as a purposeful activity: Functionalist approaches explained, St. Jerome, Manchester.

Oduyoye, M., 2008, Yoruba discourse in religion and culture, Day Star Press, Ibadan.

Ortiepp, S., 2011, Pronunciation of the tetragrammaton: A historico-linguistic approach, EBook (PDF Format), viewed 10 January 2019, from http://www.lulu.com/shop/
steven-ortlepp/pronunciation-of-the-Tetragrammaton-a-historico-linguisticsteven-ortlepp/pronunciation-of-the-Tetragrammaton-a-hist
approach/ebook/product-23755197.html?ppn=1\#productDetails.

Oseka, M., 2016, 'A textual study of the passages containing plural forms related to the generic Name of God and to the tetragrammaton in the Pentateuch', Vox Scripturae 24(2), 13-44. https://doi.org/10.25188/FLT-VoxScript(eISSN2447-7443) Scripturae 24(2), $13-44.1$
vXXIV.n2.p13-44.MO

Osunbuyide, S., 2014, Orikinile Yoruba, Osunbuyide Books, Ilorin.

Parrinder, G., 1962, West African religion, Epworth Press, London.

Phillips, A.L., 1998, 'The origin of 'I AM' in Exodus 3;14', Journal of the Society of Old Testament (JSOT), 78, 81-84. https://doi.org/10.1177/030908929802307805

Pym, A., 2004, The moving text: Localization, translation, and distribution, John Benjamins, Amsterdam.

Reiss, K. \& Vermeer, H.J., 1984, Grundlegung einer allgemeinen Translationstheorie, Niemeyer, Tubingen.

Renn, S. (ed.), 2005, 'God', Expository dictionary of Bible words, pp. 439-440, Hendrickson Publishers, Peabody.

Sachs, G., 2010, 'EHYEH-ASHER-EHYEH', Jewish Bible Quarterly 18(4), 244-246.

Schild, K., 1954, 'On Exodus 3:14 - I am that I am', Vetus Testamentum 4(4), 296-302. https://doi.org/10.2307/1515709

Shaw, F., 2016, 'Tetragrammaton: Western Christians and the Hebrew name of God: From the beginnings to the seventeenth century', The Journal of Theological Studies 67(2), 759-762. https://doi.org/10.1093/jts/flw193

Snell-Hornby, M., 2006, The turns of translation studies: New paradigms or shifting viewpoints? Benjamins, Amsterdam.

Sonek, K., 2009, 'The Divine Name in Exodus 3:14', Revue Biblique 116(2), 174-184.

Steiner, G., 1975, After Babel: Aspects of language and translation, Oxford University Press, Oxford.

Sugirtharajah, R.S., 2002, Postcolonial criticism and biblical interpretation, Oxford University Press, Oxford.

Thomas, L.R., 1990, 'Dynamic equivalence: A method of translation or a system of hermeneutic?', The Master's Seminary Journal 1(2), 161-170.

Venuti, L., (1998), The scandals of translation: Towards an ethics of difference., London and New York: Routledge, London. 